\title{
Contextualization to Enhance Students' Writing Ability
}

\author{
Humaera Silvia Maristy* \\ Graduate School \\ Universitas Negeri Yogyakarta \\ Yogyakarta, Indonesia \\ humaera.silvia90@gmail.com
}

\author{
Margana \\ Graduate School \\ Universitas Negeri Yogyakarta \\ Yogyakarta, Indonesia \\ wr1@uny.ac.id
}

\begin{abstract}
This study aims at improving the writing ability of grade seventh through contextualization at a state junior high school in the Special Region of Yogyakarta, Indonesia. Contextualization means to teach language in a context or to provide a context for language teaching to the language teaching and learning process connected with real life. The study was an action research. Three cycles consisting of nine meetings were performed. A class of grade seven students at the school was the subjects of this study. Data condensation, data display, and conclusion drawing or verification were used to analyze students' writing qualitatively. Descriptive quantitative analysis was also used to analyze the data. The results show some improvements in the students' writing ability. First, students felt that their learning was meaningful. Second, students were motivated in writing. Third, students could express their ideas and develop them into paragraphs. Fourth, students' grammatical mistakes were reduced. The result of quantitative data showed that the average scores of the content, paragraph organization, vocabulary, language use, and mechanics improved significantly. In terms of the process, the students' positive behavior on the verbal and non-verbal aspects improved while their negative behavior decreased.
\end{abstract}

Keywords - improving, writing, writing ability, context, contextualization

\section{INTRODUCTION}

Writing is one of the language skills that students must achieve. In fact, it is not easy to master writing. It is one of the most often used skills by the teachers in teaching English at all levels of education. Consequently, the skill becomes daily necessity for every person who wants to express whatever information she/he wants to communicate in written form.

Writers face some issues in writing. Brown and Lee (2015: 335) explains writing as the result of thinking, drafting, and revising procedures. It implies that a writer needs to think about the content of the writing first and then arrange the ideas using appropriate language. Writing in correct forms of language involves correct spelling, punctuation, diction, grammar, sentence and paragraph formation, et cetera. Moreover, Hedge in McDonough, Shaw and Masuhara (2013: 158) affirms that writing is the process of putting pieces of text by developing ideas through sentences and paragraphs to become a whole structure. In addition, writing is not only a group of words which is arranged neatly. It consists of many constituent parts to consider. Besides, writing also involves goals. There are four goals which a writer should achieve. They are "unity, support, organization, and error-free sentences" (Langan 2012: 17).

However, students find some problems in writing as this process needs sub-skills to master. Langan (2012: 96) argues that writing has four basic skills. They are handwriting or typing, spelling, constructing grammatical sentences, and punctuating. While in the higher level, writing involves cognitive skills, such as gathering ideas relevant to the topic, organizing them into a logical sequence, structuring the sequence into sections and paragraphs, expressing the ideas in a written draft, editing the draft, and writing out a final text. In short, writing comprises five important elements namely content, organization, vocabulary, language use, and mechanics. Writers should consider the unity or context of writing, not only the structure. In school context, students may find problems in getting ideas even in writing them into illegible sentences and paragraphs (Richards and Renandya, 2002: 303). In line with these theories, those problems of writing are found at schools in Indonesia.

Therefore, writing is quite hard to master. There are some reasons why it is difficult. First, Richards and Renandya (2002: 303) state that writing is the most difficult skill for second or foreign language learners to obtain. Second, in the theory of second language acquisition, listening becomes the earliest skill and writing becomes the latest skill and the students need to master the sub-skills in order to write well. Students are intended to master microskills of writing in order to master good writing. Based on Brown (2004:221), they need to achieve micro-skills and macro-skills that they use to write. Third, it is beneficial for junior high school students in the daily communication but it is usually not learnt intensively.

Consequently, the teaching of writing skill is a complex activity. Teachers of English should alternate the teaching learning process to fix the problems. Based on the researcher's classroom preliminary observation, interviews, and questionnaires at a class of seventh grade in a state junior high school in the Special Region of Yogyakarta, Indonesia, the teacher did not apply contextual activities of teaching writing so that the activities were demotivating and less meaningful. Applicable contexts of situations are not taught intensively in this junior high school level. Students' interest became less and less so that students began to create negative stimuli about learning and motivation to write. 
Based on Hymes (1974) in Wardhaugh and Fuller (2015:88), context is important to make the text meaningful. That is why we need relevant and meaningful context of situation in teaching. Without the meaningfulness, the teaching and learning activity is useless.

Since the problems emerged, a strategic solution was chosen in order that the action can improve the seventh grade students' writing ability through contextualization. In the terms of contextualization, the word "context" here refers to context of situation. As Hymes (1974) in Wardhaugh and Fuller (2015:88) states, context is important to make the text meaningful. Those kinds of contexts can be presented in the forms of contextual activities. Those activities are completed with relevant context of situations by doing contextualization. Mazzeo, Rab, and Alssid (2003) in Perin (2011:4) propose it as a teaching strategy which makes a relationship between what the students learn in the classroom and the real life they need to practice.

Lee and Sakamoto (2012:13-19) propose the model of contextualized education which concerns with some aspects which are presented in the following figure.

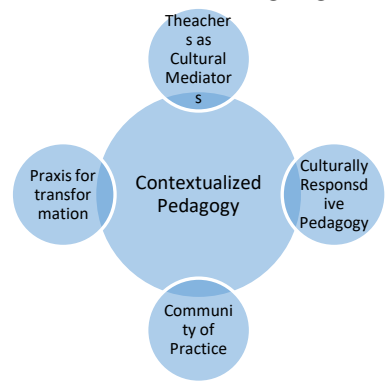

Fig. 1. Models of contextualized education by Lee and Sakamoto (2012:13)

Margana (2011:84-85) states that the English teachers may consider three issues related to the context of situation including participant), topics, and setting. First, participants of the communication and kind of the relationship they have need to be described by the English teacher. Second, providing the setting of the communication is important to avoid students' confusion of comprehending the text whether it is formal or non-formal, relaxed or serious, and so on. Third, the English teachers should show the topics and types of communicative events so the meaningful context can be gained.

Margana (2011:85) also proposes the description of how context is established. The summary is as follows.

TABLE 1. THE DESCRIPTION HOW CONTEXT IS ESTABLISHED (MARGANA, 2011:85)

\begin{tabular}{|c|c|c|}
\hline Participants (P) & Topics (T) & Setting $(\mathrm{S})$ \\
\hline $\begin{array}{l}\text { Who are } \\
\text { involved in the } \\
\text { communication? }\end{array}$ & $\begin{array}{l}\text { What do they } \\
\text { talk about? }\end{array}$ & $\begin{array}{l}\text { Where does the } \\
\text { communication } \\
\text { take place? }\end{array}$ \\
\hline $\begin{array}{l}\text { What is the } \\
\text { relationship } \\
\text { between them? }\end{array}$ & $\begin{array}{l}\text { What is the } \\
\text { purpose of the } \\
\text { communication? }\end{array}$ & $\begin{array}{l}\text { When do the } \\
\text { participants } \\
\text { conduct a } \\
\text { communication? }\end{array}$ \\
\hline $\begin{array}{l}\text { What social } \\
\text { backgrounds do } \\
\text { the participants } \\
\text { have? }\end{array}$ & $\begin{array}{l}\text { How is the topic } \\
\text { conveyed? }\end{array}$ & $\begin{array}{l}\text { What social } \\
\text { environment is } \\
\text { it? }\end{array}$ \\
\hline
\end{tabular}

The advantages of writing also enhance the students' motivation. It is in line with the study of Perin (2011:1) that aimed to facilitate students' learning through giving contexts and explores the nature and effectiveness of contextualization as a way to improve outcomes for academically underprepared college students. Perin (2011:1), in his research on the use of contextualization, found that using relevant contexts aids students in maintaining motivation since the teaching and learning process became meaningful. Moreover, students were facilitated to learn across subjects without distracting each other. In addition, contextualization can facilitate students to memorize what they have learnt because the teaching and learning process is meaningful. Unlike the decontextualized one, Oxford and Scarcella (1994) in Nemati (2010: 172) (2009: 1) observed that while 'de-contextualized learning' (word list) may help students memorize vocabulary for tests, however, students are likely to rapidly forget words memorized from lists. Therefore, what we need is contextualized learning.

With regard to the memorization, a teacher can add contexts of situation to help the students ensure their longterm interpretation. With the use of contextualizer, the teaching and learning process adds the required context information to objects to be archived, in order to ensure their long-term interpretation. It also manages context evolution and re-contextualization into the current (typically changed) context when they need to call back into active use. (Nieder'ee 2015: 4)

Thus, the strategy of contextualization is needed to solve the problem of improving the student' writing abilities. This research is aimed to find how the students' writing ability can be enhanced through contextualization. At the end of the study it is expected that contextualization can help students in improving their writing ability.

\section{METHOD}

This study was an action research which follows Kemmis and Taggart's model (1988 cited in Burns, 2010:9) of action research with some modification. The process of the action research consists of four stages such as planning, action, observation, and reflection.

Three cycles consisting of nine meetings were performed. The seventh grade students were the subjects of this study and an English teacher was the researcher's collaborator. The data were acquired through classroom observations in the classroom, questionnaires for the students, documentations, and interviews with the students and collaborator.

There are four indicators that can mark the success of the research as follows: (1) students can generate ideas well, (2) they can use the correct grammatical features, (3) they can organize the paragraph well, and (4) they can improve their motivation.

The research must fulfill the indicators to be success. However, if the actions are unsuccessful, the researcher and the collaborator will try to find another suitable action to use contextualization in teaching writing. To fulfill the dialogic 
validity, the researcher works with the English teacher as the collaborator to review the value of the research which had been conducted.

Field notes, the results of observation checklist forms, questionnaires results, interview transcripts, and documentations were the forms of the data. "Data condensation, data display, and conclusion drawing/verification" were used to analyze the data qualitatively. Descriptive quantitative analysis was used to analyze the students' writing quantitatively.

The data were analyzed in three steps namely data condensation, data display, and conclusion drawing/verification (Miles, Huberman, and Saldana, 2014: 10-12). Firstly, the researcher selected, focused, simplified, abstracted, and transformed the data which were in the form of observation checklist forms, interview transcripts, field notes, and samples of students' writing. The researcher, then, sorted, sharpened, focused, and organized the data to get the final conclusion. Furthermore, the data were organized in order to come to the conclusion drawing and action. Finally, she drew conclusion from the data display to know the progress of the implementation and verified it.

In addition, the quantitative data were taken from assessing students' writing performance by using a writing rubric adapted from Jacobs et al. in Weigle (2002: 116). The rubric provided five aspects of writing namely content, organization, vocabulary, language use, and mechanics and each of them was scaled from 1 to 4 . Hence, the maximum score was 20 , while the minimum score was 5 . To analyze the quantitative data which were in the form of students' writing performance task scores, the researcher used descriptive qualitative analysis.

\section{RESEARCH FINDING AND DISCUSSION}

\section{A. Research Finding}

To identify problems emerging in the field, preliminary classroom observation, pre-test and interview were done. The English teacher, the students of the studied class, and the collaborator were interviewed and the teaching and learning process was also observed. It can be implied that the English teaching and learning process did not run very well. The students were noisy during the lesson as they were not interested to the English lesson. In addition, they had difficulties in mastering English too, especially writing. The problems could also be seen from the result of the interview.

After the implementation, some fails and improvements were found during the process of the action with the strategy of contextualization which provided contexts of situation.

In Cycle 1, students showed improvements on the idea generation and motivation but they still found some problems in the teaching learning process of writing. They could not apply grammar and organize the paragraph well. They also felt confused with contexts of situation so that the teacher should give more explanation about it. It can be seen in the following field note:

\section{R: Researcher Ss: Students}

After all group had already finished the task, $\mathrm{R}$ asked one member of each group to attach the work on the white board. The group which was earlier I attaching the work was placed in the left side, arranged in line based on the order of the submission. The students ran as they wanted to be the first. The situation became noisy for a moment because they were so enthusiastic. $\mathrm{R}$ then gave numbers based on the order. $\mathrm{R}$ and $\mathrm{S}$ corrected the works together and gave feedback on the group work. Every student shouted to give their comment. Finally, it was found that group 2 was the best and the fastest group which submitted the work. (Field Note 14, May $11^{\text {th }}, 2015$ )

The improvement laid on students' motivation in writing. By applying group works with contextualization, the students were enthusiastic in learning the materials and doing the writing tasks. It can be proven from these following data:

$\mathrm{R}$ : OK, then by using contexts of situations, did you like the writing activity?')

Ss : We liked it, Ma'am.(S11)

$\mathrm{R}$ : Why?

Ss : Itwas fun, we were not only asked to write directly.(S11) It was interesting.(S20) (S19)

R: Researcher Ss: Students (Interview 6, May 13 ${ }^{\text {th }}$, 2015)

Furthermore, the weakness dealing with the low students' mastery of grammar emerged and can be seen in the following interview transcripts:

$\mathrm{R}$ : Then, did you find any terrible difficulties?

Ss : The meaning, Miss.(S11)(S16)

The most difficult was ordering into a good sentence.(S17)

Yes, when I was writing a sentence, it was messy.(laughing together) (S16)

$\mathrm{R}$ : Oh, so you are still confused on grammar, right?

Ss : Yes, Miss.(S6)(S20)

R: Researcher $\quad$ Ss: Students (In view 7,May 13 ${ }^{\text {th }}, 2015$ ) Thus, the cycle was continued to Cycle 2.

In Cycle 2, improvements laid on students' writing skills, such as students' motivation, generating ideas, and paragraph organization. Afterwards, some questions related to them were asked. There was a better interaction between the researcher and the students. However, the problems of grammar were still noticeable. It can be seen in the following field note:

\section{R: Researcher Ss: Students}

Before starting the main lesson, $\mathrm{R}$ shared the material for Ss. First, R tried to grab Ss' attention by showing pictures so that Ss looked enthusiastic. Ss that usually made noise looked enthusiastic, they were active in responding R's questions and they liked to do their works. $\mathrm{R}$ tried to build contexts which were relevant to the students' real life so that they felt engaged and realized the usage. Ss then did the task in groups. The interaction among the group members was good. After a brief discussion, they divided the task. One of them wrote and the others thought and looked for difficult 
vocabulary on the dictionary and notes.

(Field Note 19, May 21 ${ }^{\text {st }}, 2015$ )

By looking at the results showed in this cycle which had shown good improvements in students' writing skills. It also can be seen from these following data:

$\begin{array}{ll}\mathrm{R} & \text { : How did it help you? } \\ \text { Ss } & \text { : I could get idea. I could think when I } \\ & \text { was the person who had to write the }\end{array}$ text in the reality. (S16)

I did not become confused aboutwhat to rite and connected. (S19)

It made easier to write. (S20)

$\mathrm{R} \quad$ : What improvement did you you got?')

Ss : Now, I can make sentences correctly then connect them. (S20)

I have known the aim of the writing based on the example. (S18)

R: Researcher Ss: Students (Interview 9, May 25 ${ }^{\text {th }}$, 2015)

However, students' grammatical mistakes were still found because there was only little explanation on grammar and it needed to be more contextualized. Therefore, the researcher and the collaborator decided to continue the cycle to improve more the students' writing skill especially grammar. It can be seen from these following data:

$\mathrm{R}$ : Oh, so you were helped to find ideas and connect them, right? Well, did you still find any difficulties?

Ss : Yes, I'm still confused in making correct senntences. (S16)

Yes, how to construct.Dictionaries only provide words with many meanings. (S19)

$\mathrm{R}$ : Oh, I see, so generating ideas is alredy clear but you still make mistake in constructing sentences, right?

Ss : Yes, Miss. (S20)

Yes, I am still confused. Please explain it more tomorrow, Miss. (S18)

R: Researcher $\quad$ Ss: Students (Iterview 9, May 25 ${ }^{\text {th }}, 2015$ )

In Cycle 3, it could improve all the students' writing skills. By looking at the results showed in this cycle which had shown good improvements in students' writing skills, the researcher and the collaborator decided to stop the cycle. The improvements can be seen in the observation. The situation can be seen in the field note below.

\section{R: Researcher Ss: Students}

After $\mathrm{S}$ already understood, $\mathrm{P}$ continued learning on the stage of ICOT (Independent Construction of the Text). P shared the individual task to make an individual text based on the context dan the picture given. $\mathrm{P}$ shared two kinds of photos and contexts of situation randomly to minimize Ss cheat. The class situation was quiet when $\mathrm{S}$ was seriously doing the individual task. $\mathrm{R}$ and $\mathrm{C}$ walked around to watch the Ss' individual activity without disregarding to remind Ss to always pay attention to the writing detail.

(Field Note 25, June 3rd, 2015)
The students were enthusiastic in writing which affected their writing ability in terms of ideas generation, paragraph organization, as well as grammatical mastery concurrently. It can be seen from these following data:

(4:16)R : Nah, can you write now?

Ss : Yes, quite good, Miss. (S16)

I can. (S19)

I can, Miss. (S20)

$\mathrm{R}$ : Do you still feel confused in the grammar?

Ss : No, Ma'am. I already understand.(S16)

I can. (S19)

Me too, Ma'am.(S20)

No, my mistakes reduced.(S18)

$\mathrm{R}$ : What improvement did you you get?

Ss : Now, I can make sentences correctly then connect them. (S20)

I have known the aim of the writing based on the example. (S16)

I'm not confused in writing again, making sentences also.(S19)

R: Researcher Ss: Students (Interview 13, June 3rd, 2015)

The quantitative data to support the qualitative data were also acquired though the classroom observation and also writing assessment. In the process the improvements were also calculated as follows.

TABLE 2: THE IMPROVEMENTS ON THE PROCESS

\begin{tabular}{|c|c|c|c|c|c|}
\hline \multirow[b]{2}{*}{ Aspects } & \multirow[b]{2}{*}{ Indicators } & \multicolumn{4}{|c|}{ Cycle } \\
\hline & & $\begin{array}{l}\text { Before } \\
\text { the } \\
\text { Action }\end{array}$ & 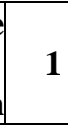 & 2 & 3 \\
\hline \multirow{7}{*}{ Verbal } & $\begin{array}{l}\text { 1. Students ask } \\
\text { questions related } \\
\text { to the material. }\end{array}$ & 3 & 15 & 18 & 21 \\
\hline & $\begin{array}{l}\text { 2. Students } \\
\text { comment based } \\
\text { on the material. }\end{array}$ & 4 & 25 & 28 & 28 \\
\hline & $\begin{array}{l}\text { 3. Students talk on } \\
\text { different topics } \\
\text { with friends. }\end{array}$ & 22 & 15 & 11 & 7 \\
\hline & $\begin{array}{l}\text { 4. Students answer } \\
\text { the question } \\
\text { from the teacher. }\end{array}$ & 14 & 26 & 25 & 28 \\
\hline & $\begin{array}{l}\text { 5. Students joke } \\
\text { with friends }\end{array}$ & 18 & 12 & 8 & 6 \\
\hline & $\begin{array}{l}\text { 6. Students talk by } \\
\text { themselves on } \\
\text { different topics. }\end{array}$ & 17 & 9 & 10 & 5 \\
\hline & $\begin{array}{l}\text { 7. Students are not } \\
\text { active. }\end{array}$ & & 4 & - & - \\
\hline \multirow[t]{2}{*}{$\begin{array}{l}\text { Non- } \\
\text { verbal }\end{array}$} & $\begin{array}{l}\text { 1. Students look } \\
\text { enthusiastic on } \\
\text { the learning } \\
\text { process. }\end{array}$ & 14 & 21 & 25 & 26 \\
\hline & 2. Students & & 16 & 22 & 29 \\
\hline
\end{tabular}




\begin{tabular}{|l|l|l|l|l|l|}
\hline confident. & & & & \\
\cline { 2 - 6 } & $\begin{array}{l}\text { 3. Students look } 24 \\
\text { shame. }\end{array}$ & 12 & 6 & 6 \\
\cline { 2 - 6 } & $\begin{array}{l}\text { 4. The students are } \\
\text { ignorant. }\end{array}$ & 4 & 4 & 2 \\
\hline $\begin{array}{l}\text { 5. The students pay } \\
\text { attention to their } \\
\text { friends. }\end{array}$ & 7 & 4 & 4 \\
\hline
\end{tabular}

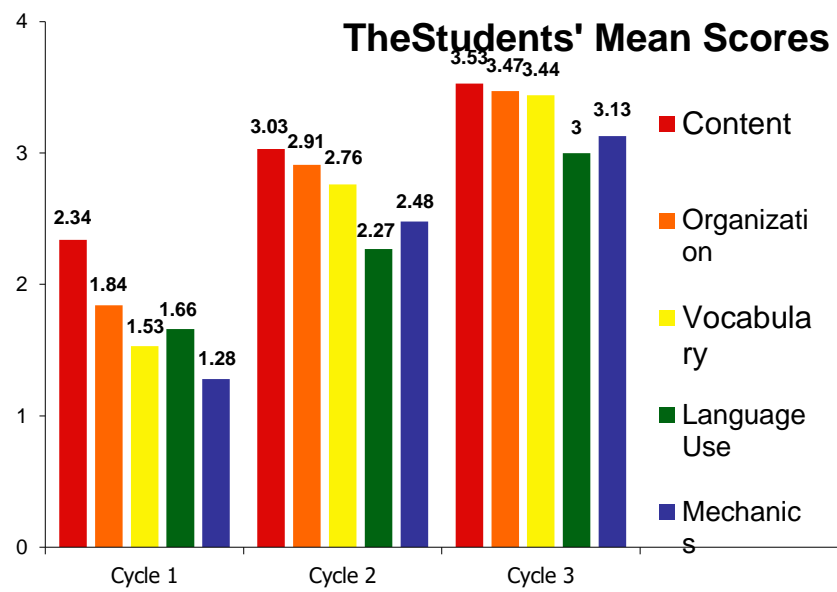

Chart 1. Mean of writing sub-skills scores in cycle 1-3

In Cycle 1, the mean score of the students' writing skill was 2.34 for the content, 1.84 for the organization, 1.53 for the vocabulary, 1.66 for the language use, and 2.35 for the mechanics. It can be implied that the actions implemented in Cycle 1 were successful to improve students' motivation and students' writing skills in term of ideas generation. However, there were still some problems occurred dealing with the teaching-learning process and the students' grammatical mastery and paragraph organization. Consequently, the researcher and the collaborator continued the cycle.

In Cycle 2, the mean score of the students' writing skill was 3.03 for the content, 2.91 for the organization, 2.76 for the vocabulary, 2.27 for the language use, and 2.48 for the mechanics. It can be implied that the actions implemented in Cycle 2 were successful to improve students' motivation and students' writing skills in terms of generating ideas, and paragraph organization. However, there were still some problems occurred dealing with the teaching-learning process and the students' grammatical mastery. Consequently, the researcher and the collaborator decided to continue the cycle.

In Cycle 3, the mean score of the students' writing skill was 3.53 for the content, 3.47 for the organization, 3.44 for the vocabulary, 3 for the language use, and 3.22 for the mechanics. It can be implied that the actions implemented in Cycle 3 were successful to improve students' writing skills in terms of generating ideas, paragraph organization, and grammatical mastery. Therefore, the researcher and the collaborator decided to stop the cycle.

The quantitative data were acquired from the gain scores of the five writing aspects. However, to ease the interpretation, the researcher presents a conversion table consisting of six categories namely "very poor", "poor", "fair", "good", "very good", and "excellent".

TABLE 3: CONVERSION TABLE OF STUDENTS' WRITING SCORES

\begin{tabular}{|c|c|c|c|c|c|}
\hline \multirow{2}{*}{$\begin{array}{c}\text { Class } \\
\text { Interval }\end{array}$} & \multirow{2}{*}{$\begin{array}{c}\text { Categori- } \\
\text { zation }\end{array}$} & \multicolumn{4}{|c|}{ Frequency } \\
\cline { 3 - 6 } & $\begin{array}{c}\text { Pre- } \\
\text { Test }\end{array}$ & $\begin{array}{c}\text { Cycle } \\
1\end{array}$ & $\begin{array}{c}\text { Cycle } \\
2\end{array}$ & $\begin{array}{c}\text { Cycle } \\
3\end{array}$ \\
\hline $\begin{array}{c}17.5- \\
20\end{array}$ & Excellent & 0 & 0 & 4 & 17 \\
\hline $\begin{array}{c}15.0- \\
17.4\end{array}$ & $\begin{array}{c}\text { Very } \\
\text { good }\end{array}$ & 0 & 0 & 8 & 10 \\
\hline $\begin{array}{c}12.5- \\
14.9\end{array}$ & Good & 0 & 1 & 11 & 14 \\
\hline $\begin{array}{c}10.0- \\
12.4\end{array}$ & Fair & 5 & 8 & 9 & 0 \\
\hline $\begin{array}{c}7.5- \\
9.9\end{array}$ & Poor & 8 & 13 & 0 & 0 \\
\hline $\begin{array}{c}5.0- \\
7.4\end{array}$ & $\begin{array}{c}\text { Very } \\
\text { poor }\end{array}$ & 18 & 10 & 0 & 0 \\
\hline
\end{tabular}

Then to categorize the level of the ability into groups, the rater used scale of ability. The conversion showed that students' scores of writing improved every meeting. Based on the table, it can be interpreted that in the pre-test, the students' scores were categorized into "fair", "poor", and mostly "very poor". Some students showed the "very poor, "poor", and "fair" and only one student who was "good". In the second cycle, however, the numbers of "good" and "fair" categories increased. Meanwhile, the "very good" and "excellent" scores were achieved and no one got "poor" and "very poor" scores in this cycle. Finally, in the third cycle, "very poor" and "poor" scores did not exist. The "excellent category" were gained by most students and some others were included into "good" and "very good" category.

In brief, by applying contextualization, students have experienced writing with a purpose. They can apply the communicative purpose in their real life. In addition, contextualization improved the effectiveness of writing so that students' task achievement of writing improved. Therefore, the research cycles were stopped.

\section{B. Discussion}

Since the quantitative and qualitative data were acquired in terms of the process and the products of writing, the aspects of the indicators can be discussed as follows.

TABLE 4: THE INDICATORS OF THE RESEARCH SUCCESS

\begin{tabular}{|l|c|c|c|}
\hline \multirow{2}{*}{\multicolumn{1}{c}{ Aspects }} & \multicolumn{3}{c|}{ Cycle } \\
\cline { 2 - 4 } & $\mathbf{1}$ & $\mathbf{2}$ & $\mathbf{3}$ \\
\hline Students' Motivation & $\sqrt{ }$ & $\sqrt{ }$ & $\sqrt{ }$ \\
\hline Generating Ideas & $\sqrt{ }$ & $\sqrt{ }$ & $\sqrt{ }$ \\
\hline Paragraph Organization & - & $\sqrt{ }$ & $\sqrt{ }$ \\
\hline Grammar & - & - & $\sqrt{ }$ \\
\hline
\end{tabular}


The table shows that there were improvements on the students' writing subskills from cycle to cycle. In the beginning students felt English, especially writing, was less meaningful to learn because they never used English in everyday life. Because of that reason, a solution should be done. The chosen solution was giving contextualization on every task. The application of the contextualization shows that they need English, especially writing English, in many aspects of their life. Furthermore, they could get their ideas and change their assumption that writing was not useful in their life.

Moreover, that result was in line with the theory from Allwright (1998:72) that contextualization can help teachers in creating exciting learning atmosphere so that the activities are not boring. The results of this study were hand in hand with the theory that by providing contexts of situation, students can feel that the teaching-learning process of writing is meaningful so that they can be motivated in learning. Therefore, it is concluded that the meaningfulness of the activity can make students motivated and improve their engagement in learning, especially learning writing.

Besides, contextualization can help students to minimize ideas and paragraph organizations problems, as what Allwright (1998:123) also argued that contextualization provides related information which is useful for them to generate ideas. Through the use of contextualization, students can structure and organize their writing in a way that fits its purpose. Thus, after understanding the information of the text, students are helped to get ideas. Furthermore, they can organize their ideas into a structural text. Moreover, grammatical mastery was the last emerging problem. The strategy to improve students' skill of generating ideas by using contextualization can show result from Cycle 1. Meanwhile, the strategy to improve students' skill of paragraph organization by using contextualization can show result from Cycle 2.

Moreover, contextualization can solve this problem through giving contextual grammatical input. It supports Shin (2006) in Margana (2012:107). He states that language structures should be presented within a context that is meaningful and communicative. Therefore, contextualization which is meaningful and communicative can facilitate students to learn structure of English. In conclusion, by using contextualization, the students' motivation and generating ideas skill could be improved only in one cycle while the paragraph organization skill needed two cycles to improve. Meanwhile, the grammar aspects could be improved in three cycles. Thus, the grammatical mastery was most difficult skill to improve by using contextualization than three other skills.

The results match the final qualitative data in the last cycle that every aspect of the assessment is included in the category of "good" at least. The mean score of the students' writing skill was 3.53 for the content, 3.47 for the organization, 3.44 for the vocabulary, 3 for the language use, and 3.22 for the mechanics. Therefore, either the qualitative or the quantitative data show significant improvement on the students' writing ability.
As the final reflection, the result of this research was discussed by the researcher and the English teacher as the collaborator. Furthermore, they drew a conclusion that contextualization can be an effective tool to help students in doing the writing. Therefore, after the result of the last cycle had shown a significant improvement in students' writing skills, the researcher and the collaborator decided to stop the cycle.

\section{CONCLUSION}

This study is about improving students' writing ability through contextualization. Contextualization is providing intermediate setting which surrounds the communication It is useful to make tasks meaningful to students. The contexts used to improve students' writing ability were contexts which were familiar and relevant to students' real life and based on the goal. Since contextualization was used in the teaching writing combined with group work, the students were enthusiastic in the class. Moreover, by applying contextualization, students and teacher considered that the teaching and learning processs was meaningful. In addition, their writing ability improved. They could express their ideas and develop them to be relevant to the topic and supporting sentences. Their grammatical mistakes were also minimized. The students' improvement in writing ability has been presented in the form of a mean scores table.

In terms of the process, there are some improvements on the verbal and non-verbal aspects. In the verbal aspect, the number of students who asked questions based on the material, commented based on the material, and their respond improved. Meanwhile, the number of students who talked on different topics with friends, joked with friends, talked by themselves on different topics, and kept silent and did not answer the teacher's question decreased. In terms on non-verbal aspect, the number of students who looked enthusiastic on the learning process and looked confident increased. Meanwhile, that of students who looked shy, did not pay attention to the teacher's explanation, paid attention to their friends, played something in the classroom, read other books, and did the task of other subjects decreased.

The results of the research give some implications to the research members. Theoretically, the researcher expects that the result of this study can strengthen the theories on education, especially on the use of contextualization as a method in the teaching and learning processes of writing. In the theoretical review, there are the theories stated by Allwright (1998) that the contextualization can help students to motivate, create interest, and combat boredom during the writing process. The researcher expects that the result of this study can strengthen the theories on education, especially on the use of contextualization as a method in the teaching and learning processes of writing. In the theoretical review, there are the theories stated by Allwright (1998) that the contextualization can help students to motivate, create interest, and combat boredom during the writing process. This teaching strategy can be used to create a nonthreatening environment, which encourages students and promotes positive social interaction that can support to develop students' motivation. 
Besides Allwright's (1998) theory also states that contextualization is useful for students to generate ideas. Through the use of contextualization, students can structure and organize their writing in a way that fits its purpose.

Moreover, Shin's (2006) theory that contextualization can facilitate students to learn grammar in contexts is also apllicable. The grammar the students learn can be applied meaningfully in the daily life. Thus, language structures should be presented within a context that is meaningful and communicative. In order to gain the goal of learning English, in this case, developing the students' writing achievement.

Practically, the research findings can be used by English teachers as a consideration in choosing strategies for the English teaching and learning processes to achieve students' writing achievement. They can be references for teachers to involve their students in the classroom through confronting real-world issues and problems and acting in a collaborative fashion to create problem solution.

\section{ACKNOWLEDGMENT}

I would like to express my gratitude to all those who have, know or otherwise, helped to shape the ideas that have gone into this research.

\section{REFERENCES}

Allwright, D. (1998). Contextual factors in classroom language learning: an overview. in: Malmkjaer, K. and Williams, J. (eds.). Context in Language Teachers and Learners: Investigating the Language Classroom. Cambridge: Cambridge University Press.

Brown, H. (2004). Language Assessment Principals and Classroom Practices.New York: Longman.

Brown, H., \& Lee, H. (2015). Teaching by Principles: An Interactive Approach to language Pedagogy $\left(4^{\text {th }}\right.$ Ed.). New York: Pearson Education ESL.

Burns, A. (2010). Doing Action Research in English Language Teaching: A Guide for Practioners. New York: Taylor and Francis Group.

Haris, D. P. (1974). Testing English as a Second Language. New York: McGraw Hill Book Company.

Langan, J. (2012). English Skills (10th Ed.). New York: McGraw-Hill Companies, Inc.
Lee, H., \& Yee-Sakamoto, I. (2012, October). Contextulized Pedagogy: New Eductional approach in the postmodern era. The Journal of $\begin{array}{llll}\text { Multicultural Education. } & 8(2) . & \text { Retrieved } & \text { from }\end{array}$ http://www.wtamu.edu/journal/volume-8-number-2.aspx

Margana. (2011). The importance of Situational Context in Teaching Speaking as one of Productive Language Skill. Journal of the $8^{\text {th }}$ National JETA Conference, 84-85 Retrieved from http://staff.uny.ac.id/files/JETA 82011

Margana.(2012). Teaching Young Learners with the Use of Contextualized Language Instruction. Journal of the $2^{\text {nd }}$ National Conference of Young Learners in Indonesia (TEYLIN). Retrieved from http://staff.uny.ac.id/sites/default/files/penelitian/Dr.\%20Margana,\%20M.H um.,M.A./TEYLIN 2011_UMK.pdf

McDonough, J., Shaw, C., \& Masuhara, H. (2013). Materials and methods in ELT: A teacher's guide (3rd edition). Oxford: Wiley-Blackwell

Miles, M. B., Huberman, A. M., and Saldana, J. (2014). A Method Sourcebook: Qualitative Data Analysis ( $3^{\text {rd }}$ Ed.). London: Sage Publications, Ltd

Nemati, A. (2010). Enhancing Long-term Retention by Memory Vocabulary Learning Strategies. The Journal Of Asia TEFL Vol. 7, No. 1, pp. 171-195. Retrieved from

http://r.search.yahoo.com/_ylt=A2oKmJkeCetYBToAnBXLQwx.; yl $\mathrm{u}=\mathrm{X} 3 \mathrm{oDMTEyOHVnczNtBGNvbG8Dc2czBHBvcwMxBHZ0aWQD}$ STAzMzBfMQRzZWMDc3I/RV=2/RE $=1491827103 / \mathrm{RO}=10 / \mathrm{RU}=\mathrm{ht}$ tp\%3a\%2f\%2fwww.asiatefl.org\%2fmain\%2fdownload pdf.php \%3fi \%3d185\%26c\%3d1419308389/RK=0/RS=mjZjHa8ADj7iPz7bpM5d vOOdr3g-

Nemati, A. (2009). Memory vocabulary learning strategies and long-term Retention. International Journal of Vocational and Technical Education Vol.1 (2), pp. 014-024, October 2009. Retrieved from http://www.academicjournals.org/article/article1379328836_Nemati.pdf

Nieder'ee, C. (2015). Learning from Human Memory: Managed Forgetting and Contextualized Remembering for Digital Memories. Proceedings of the 5th International Workshop on Semantic Digital Archives (SDA 2015). Retrieved from http://ceur-ws.org/Vol-1529/paper1.pdf

Perin, D. February (2011). Facilitating Student Learning Through Contextualization. CCRC Working Paper No. 29. Retrieved from http://ccrc.tc.columbia.edu/publications/facilitating-student-learningcontextualization.html?UID $=882$

Richards, J.C. and Renandya, W.A. Ed. (2002). Methodology in Language Teaching: An Anthology of Current Practice. Cambridge: Cambridge University Press.

Wardhaugh, R. \& Fuller, J. M. (2015). An introduction to sociolinguistics - 7th ed. Oxford: Blackwell Publishing Ltd.

Weigle, S.C. (2002). Assessing Writing. Cambridge: Cambridge University Press. 